\title{
HUBUNGAN TINGKAT PENDIDIKAN, PENGETAHUAN, DAN SIKAP DENGAN KEPEMILIKAN JAMBAN KELUARGA PADA MASYARAKAT DI DUSUN PONCI DESA POLEWALI KABUPATEN BULUKUMBA
}

\author{
${ }^{1}$ Safruddin \\ ${ }^{2}$ Nursyamsi
}

1Program Studi S1 Keperawatan Stikes Panrita Husada Bulukumba ${ }^{2}$ Program Studi S1 Keperawatan Stikes Panrita Husada Bulukumba

\author{
Alamat Koresponden: \\ Safruddin \\ Program Studi Ilmu Keperawatan \\ Sekolah Tinggi Ilmu Kesehatan Panrita Husada \\ Bulukumba, 04132514721 \\ Hp. 085342577075 \\ Email: Safar yahya @ymail.com
}




\begin{abstract}
Abstrak
Jamban keluarga merupakan salah satu dari berbagai masalah kesehatan yang perlu mendapat prioritas. Penyediaan sarana pembuangan tinja tidaklah mudah karena menyangkut peran masyarakat dan perilaku masyarakat. Melihat fenomena yang ada dan berdasarkan hasil penelitian didapatkan di Dusun Ponci merupakan salah satu Dusun yang memiliki permasalahan kepemilikan jamban keluarga yang tidak hanya diakibatkan oleh tingkat pendidikan, tingkat pengetahuan dan sikap masyarakat tetapi, berbagai alasan responden yaitu kurangnya sanitasi air bersih. Penelitian ini bertujuan untuk mengetahui tingkat pendidikan, tingkat pengetahuan, dan sikap dengan kepemilikan jamban keluarga di Dusun Ponci Desa Polewali Kabupaten Bulukumba. Penelitian ini menggunakan desain Observasional Analitik dengan pendekatan Cross Sectional Study. Sampel dalam penelitian dipilih dengan metode Cluster Sampling sebanyak 60 kepala keluarga. Metode pengumpulan data dilakukan dengan menggunakan lembar obervasi (lembar cek list), wawancara dan koesioner. Data dianalisis dengan analisis univariat dan bivariat dengan menggunakan uji statistic Chi Square Linear Association. Hasil penelitian menunjukkan bahwa tingkat pendidikan $(\mathrm{p}=0,001)$, tingkat pengetahuan $(\mathrm{p}=0,001)$, dan sikap $(0,000)$ berhubungan dengan kepemilikan jamban keluarga. Dengan kata lain ada hubungan yang bermakna antara tingkat pendidikan, tingkat pengetahuan dan sikap dengan kepemilikan jamban keluarga.
\end{abstract}

Kata kunci : Jamban Keluarga, Tingkat Pendidikan, Tingkat Pengetahuan dan Sikap.

\begin{abstract}
Family latrines are one of many health problems that need to be prioritized. Provision of fecal disposal facilities is not easy because it involves the role of society and community behavior. Looking at the existing phenomenon and based on the results obtained in Ponci Hamlet is one of the hamlets that have problems of family latrine ownership that is not only caused by the level of education, the level of knowledge and attitude of the community but, the various reasons of the respondents is the lack of clean water sanitation. This study aims to determine the level of education, level of knowledge, and attitudes with the ownership of family latrines in Hamlet Ponci Village Polewali Bulukumba District. This research uses Analytic Observational design with Cross Sectional Study approach. The samples in this research were chosen by Cluster Sampling method of 60 families. Methods of data collection is done by using obervation sheet (check list), interview and questionnaire. Data were analyzed by univariate and bivariate analysis using Chi Square Linear Association statistic test. The results showed that education level $(p=0,001)$, knowledge level $(p=0,001)$, and attitude $(0,000)$ were related to family toilet ownership. In other words there is a meaningful relationship between education level, level of knowledge and attitude with family toilet ownership.
\end{abstract}

Keywords: Family toilet, Education Level, Level of Knowledge and Attitude 
PENDAHULUAN

Jamban keluarga merupakan salah satu dari berbagai masalah kesehatan yang perlu mendapatkan prioritas. Penyediaan sarana pembuangan tinja masyarakat terutama dalam pelaksanaannya tidaklah mudah, karena menyangkut peran serta masyarakat yang biasanya sangat erat kaitannya dengan perilaku, tingkat ekonomi, kebudayaan, pengetahuan dan pendidikan (Profil kesehatan Sul-Sel.2014).

Menurut data WHO pada tahun 2010 diperkirakan sebesar 1,1 milyar orang atau $17 \%$ penduduk dunia masih buang air besar di daerah terbuka, dari data tersebut diatas sebesar $81 \%$ penduduk yang buang air besar sembarangan (BABS) terdapat 10 negara dan Indonesia sebagai Negara kedua terbanyak ditemukan area terbuka, yaitu India (58\%), Indonesia (12,9\%), China (4,5\%), Ethiopia (4,4\%), Pakistan (4,3\%), Nigeria (3\%), Sudan (1\%), Nepal (1,3\%), Brazil (1,2\%), dan Niger $(1,1 \%)$ (WHO 2010).

Masalah kesehatan lingkungan
yang ada di Indonesia khususnya
penggunaan jamban hasil Riskesdas
menunjukkan bahwa rumah tangga yang
menggunakan fasilitas BAB milik sendiri
$(76,2 \%)$, milik bersama $(6,7 \%)$, dan

fasilitas umum (4,2\%). Meskipun sebagian besar rumah tangga di Indonesia mempunyai fasilitas $\mathrm{BAB}$ akan tetapi, masih banyak masyarakat yang melakukan BAB sembarangan tempat sebanyak (12,9\%) (Riskesdas,2013).

Hal ini dibuktikan dengan hasil wawancara dengan salah satu koordinator di bidang kesehatan lingkungan mengatakan bahwa dalam wilayah kerja puskesmas Bontonyeleng terdapat beberapa Desa yang dinaunginya diantaranya Desa Bontonyeleng, Desa Polewali, Desa Taccorong, Desa Bukit Tinggi dan ternyata masih ada desa yang tidak memiliki jamban. Berdasarkan pengambilan data awal didapatkan hasil bahwa prevalensi tertinggi yang mempunyai masalah kepemilikan jamban keluarga adalah Desa Polewali di Dusun Ponci sebanyak 172 KK yakni KK yang memiliki jamban keluarga sebanyak 111 KK dan 61 KK yang tidak memilki jamban keluarga. Beberapa yang berkaitan dengan perilaku kesehatan yaitu tingkat pendidikan, tingkat pengetahuan, dan sikap masyarakat.

Berdasarkan hasil riset yang dilakukan oleh Azswisyah tahun (2014) di Desa Sei Musam Kendit didapatkan hasil bahwa tingkat pendidikan, tingkat pendapatan, tingkat pengetahuan 
berhubungan dengan kepemilikan jamban keluarga. sejalan hasil penelitian yang dilakukan Darsada (2012) di Desa Jehem menunjukkan bahwa tingkat ekonomi, kebiasaan masyarakat, tingkat pengetahuan, tingkat pendidikan, sikap, dan peranan petugas merupakan faktor yang berhubungan dengan kepemilikan jamban keluarga.

Tujuan penelitian ini adalah untuk menganalisis apakah ada hubungan antara tingkat pendidikan, tingkat pengetahuan, dan sikap masyarakat dengan kepemilikan jamban Keluarga di Dusun Ponci Desa Polewali tahun 2017.

\section{METODE}

Desain penelitian yang digunakan dalam penelitian ini adalah desain penelitian Cross Sectional (Setiadi, 2013), yang bertujuan untuk mengetahui hubungan tingkat pendidikan, pengetahuan, dan sikap dengan kepemilikan jamban keluarga di Dusun Ponci Desa Polewali Kabupaten Bulukumba.

Populasi adalah keseluruhan jumlah yang terdiri atas obyek atau subyek yang mempunyai karakteristik dan kualitas tertentu yang ditetapkan oleh peneliti untuk diteliti dan kemudian ditarik kesimpulannya (Setiadi, 2013). Populasi dalam penelitian ini adalah seluruh kepala keluarga (KK) di Dusun Ponci Desa Polewali Kabupaten Bulukumba sebanyak $172 \mathrm{KK}$.

Penarikan sampel menggunakan teknik Cluster Sampling dimana metode pengambilan sampel bila obyek yang akan diteliti atau sumber data yang sangat luas, maka pengambilan sampelnya berdasarkan daerah populasi yang telah ditetapkan (Sujarweni, 2014). Jumlah sampel dalam penelitian ini adalah 60 Kepala keluarga.

Instrumen yang digunakan dalam penelitian ini terdiri dari 3 jenis yaitu menggunakan lembar observasi, wawancara dan koesioner, lembar observasi digunakan untuk melihat kepemilikan jamban keluarga. Wawancara digunakan untuk mengetahui tingkat pendidikan. Sedangkan koesioner digunakan untuk mengumpulkan data tentang tingkat pendidikan, pengetahuan,dan sikap tentang jamban keluarga. Instrument penelitian (koesioner) harus memenuhi persyaratan yaitu valid dan reliable.

Data dianalisis berdasarkan skala ukur dan tujuan penelitian dengan menggunakan perangkat lunak program komputerisasi. Data dianalisis secara : (1). Analisis Univariat, Analisis dilakukan untuk melihat proporsi. (2). Analisis 
Bivariat, Uji bivariat dilakukan untuk mencari hubungan antara variabel independen dan variabel dependen dengan uji yang digunakan adalah chi-square bila memenuhi syarat, dan akan dilakukan uji gabung sel dan fisher's exact sebagai alternative. Interval kepercayaan yang diambil adalah $95 \%$ dan batas kemaknaan yang diterima apabila $\mathrm{p}<0,05$.

\section{HASIL}

Berdasarkan (Tabel 1) menunjukkan sebagian besar umur responden berada pada kategori dewasa sebanyak 37 orang $(61,7 \%)$, sebagian besar responden berjenis kelamin laki-laki sebanyak 56 orang (93,3\%), pekerjaan responden sebagian besar bekerja sebagai petani 42 orang $(70,0 \%)$.

\section{Berdasarkan}

(Tabel

menunjukkan distribusi jumlah responden berdasarkan tingkat pendidikan, pengetahuan, dan sikap dengan kepemilikan jamban keluarga.

Tingkat pendidikan responden tingkat pendidikan paling banyak pada responden dengan kategori dasar sebanyak 29 orang $(48,3 \%)$, sedangkan paling sedikit pada responden dengan kategori menengah sebanyak 13 orang $(21,7 \%)$. Tingkat pengetahuan paling banyak pada responden dengan kategori cukup sebanyak 29 orang (48,3\%), sedangkan paling sedikit pada responden dengan kategori baik sebanyak 15 orang $(25,0 \%)$. Sikap responden sebagian besar bersikap positif sebanyak 37 orang $(61,7 \%)$. Dan kepemilikan jamban keluarga memiliki frekuensi yang sama 30 orang (50\%).

Berdasarkan (Tabel

menunjukkan hubungan tingkat pendidikan dengan kepemilikan jamban keluarga dimana kategori tidak sekolah pada kepala keluarga yang tidak memiliki jamban keluarga sebanyak 15 KK $(83,3 \%)$ lebih tinggi daripada tidak sekolah dengan memiliki jamban keluarga sebanyak $3 \mathrm{KK}$ $(16,7 \%)$ sedangkan pada tingkat pendidikan menengah pada kepala keluarga yang tidak memiliki jamban keluarga sebanyak 3 KK (25,0\%) lebih kecil dibandingkan dengan yang memiliki jamban keluarga sebanyak 9 KK (75,0\%). Hal ini menunjukkan adanya kecenderungan perbedaan presentase antara tingkat pendidikan tidak sekolah dan menengah dengan kepemilikan jamban keluarga. Hasil uji Chi-Square Linear Association didapatkan nilai $p=$ $0.001(\mathrm{p}<0,05)$, maka disimpulkan bahwa ada hubungan yang signifikan antara tingkat pendidikan dengan kepemilikan jamban keluarga. 
Hubungan tingkat pengetahuan dengan kepemilikan jamban keluarga dimana kategori baik pada kepala keluarga yang memiliki jamban keluarga sebanyak $12 \mathrm{KK}(80,0 \%)$ lebih besar dari tingkat pengetahuan baik yang tidak memiliki jamban keluarga sebanyak 3 KK (20,0\%), sedangkan untuk tingkat pengetahuan kurang pada kepala keluarga yang memiliki jamban keluarga sebanyak $3 \mathrm{KK}$ $(18,8 \%)$ lebih kecil dari tingkat pengetahuan kurang pada kepala keluarga yang tidak memiliki jamban keluarga sebanyak 13 KK (81,2\%). Hal ini menunjukkan adanya kecenderungan perbedaan proporsi antara tingkat pengetahuan baik dan kurang dengan kepemilikan jamban keluarga. Hasil uji Chi-Square Linear Association didapatkan nilai $p=0.001(\mathrm{p}<0,05)$, maka disimpulkan bahwa ada hubungan yang signifikan antara tingkat pengetahuan dengan kepemilikan jamban keluarga.

Hubungan sikap dengan kepemilikan jamban keluarga bahwa responden dengan sikap positif memiliki jamban keluarga dan memanfaatkannya sebanyak 37 orang $(61,7 \%)$ dibandingkan dengan responden yang memiliki sikap yang negatif sebanyak 23 orang $(38,3 \%)$. Hasil uji Pearson Chi-Square didapatkan nilai $p=0.000 \quad(\mathrm{p}<0,05)$, maka disimpulkan bahwa ada hubungan yang signifikan antara sikap dengan kepemilikan jamban keluarga.

\section{PEMBAHASAN}

Pada penelitian ini terlihat bahwa terdapat hubungan yang signifikan antara tingkat pendidikan, pengetahuan, dan sikap dengan kepemilikan jamban keluarga di Dusun Ponci Desa Polewali Kabupaten Bulukumba

Dari Hasil uji Chi Suare Linear Association didapatkan nilai $p=0,001$ ( $\mathrm{p}<$ 0,05), maka dapat disimpulkan bahwa ada hubungan yang signifikan antara tingkat pengetahuan dengan kepemilikan jamban keluarga. Hal ini sejalan dengan hasil penelitian tingkat pendidikan dengan kepemilikan jamban keluarga di Desa Sei Musam dengan nilai $p=0,049$.

Berdasarkan hasil penelitian menggunakan uji Chi Suare Linear Association didapatkan nilai $\mathrm{p}=0,001(\mathrm{p}<$ 0,05), maka dapat disimpulkan bahwa ada hubungan yang signifikan antara tingkat pengetahuan dengan kepemilikan jamban keluarga. Sejalan dengan hasil penelitian Pebriani, dkk (2012) didapatkan hasil bahwa ada hubungan antara tingkat pengetahuan dengan penggunaan jamban keluarga di Desa Tualang Sembilar, dengan nilai $p=0,003$. 
Hasil uji statistik penelitian menggunakan uji Pearson Chi-Square didapatkan nilai $\mathrm{p}=0.000$, maka dapat disimpulkan bahwa ada hubungan yang signifikan antara sikap dengan kepemilikan jamban keluarga. Hal ini sejalan dengan penelitian penelitian Darsada, dkk (2012) didapatkan hasil ada hubungan antara sikap dengan kepemilikan jamban keluarga, dengan nilai $p=0,000$.

\section{KESIMPULAN DAN SARAN}

Berdasarkan hasil penelitian diatas maka disimpulkan bahwa Terdapat hubungan yang singnifikan antara tingkat pendidikan, tingkat pengetahuan dan sikap dengan kepemilikan jamban keluarga pada masyarakat di Dusun Ponci Desa Polewali Kabupaten Bulukumba. Hasil penelitian semoga dapat menambah pengetahuan bagi mahasiswa di STIKES Panrita Husada Bulukumba. Dan pemerintah Desa hendaknya mempersiapkan akses air bersih agar masyarakat dapat membangun jamban keluarga.

\section{DAFTAR PUSTAKA}

Ahmadi, Ruslam. (2016). Pengantar Pendidikan : Asas \& Filsafat Pendidikan. Ar-ruzz media : Yogyakarta.

Bakti Husada. (2013). Riset Kesehatan Dasar (Riskesdas) (2013) diakses melalui http://www.depkes.go.id/reseurces/ download/general/hasil\%20riskesd as $\%$

2013.pdf pada tanggal 28 febrruari 2017.

Dharma, Kelana Kusuma. (2011). Metodologi Penelitian Keperawatan :Pedoman Melaksanakan dan Menerapkan Hasil Penelitian. Trans info media : Jakarta

Darsana, Nengah I, dkk (2012). Faktorfaktor yang Berhubungan dengan Kepemilikan Jamban Keluarga di Desa Jehem Kecamatan Tembuku Kabupaten Bangli vol 4 (2) hal 112.

Dinas Kabupaten Bulukumba. (2015). Data Penduduk dengan Akses Sanitasi yang Layak berdasarkan jenis, Kecamatan, dan Puskesmas Kabupaten Bulukumba.

Erlina, Yuli. (2015). Faktor-faktor yang Berhubungan dengan Perilaku 
Hidup Bersih dan Sehat pada Tatanan Rumah Tangga Menggunakan Jamban Sehat di Dusun II RW 04 Desa Sukakarya Kec. Surakarya Kab. Bekasi. vol 5 (1) hal 1-10.

Faisal, Azswinsyah, dkk (2014). Faktorfaktor yang berhubungan dengan rendahnya kepemilikan jamban keluarga dan personal hygiene dengan kejadian diare di Desa Sei Musam Kendit Kecamatan Bahorok Kabupaten Langkat. Hal 1-9.

Germas. (2016). Masyarakat Hidup Sehat Indonesia Kuat.

Diakses melalui http://dinkes.acehp rov.go.id/upload/panduan-HKN52-tahun2016.pdf pada tanggal 20 januari 2017

Kementerian Kesehatan RI. (2015). Data Dan Informasi Tahun 2014 (Profil Kesehatan Indonesia). Diakses mel alui http://www.depkes.go.id/resou rces/ download/pusdatin/profilkesehatan-indonesia/profilkesehatan-indonesia-2014.pdf pada tanggal 28 februari 2017.

KNEPK. (2012). Etika Penelitian.

Lestari, Titik (2015). Kumpulan Teori untuk Pustaka Penelitian
Kesehatan. Nuha medika : Yogyakarta.

Maryunani. Anik. (2013). Perilaku Hidup Bersih dan Sehat (PHBS). Jakarta : TIM Narasi. (2014). Profil Kesehatan Sulawesi Selatan. Diakses melalui http ://dinkes. Sul-sel prov.go.id/files/Narasi2014.pdf

Nursalam. (2016). Metodologi Penelitian Ilmu Keperawatan : Pendekatan Praktis.ed : 4. Salemba : jakarta Notoadmodjo, Soekidjo. (2010). Ilmu Perilaku Kesehatan. Rineka cipta : Jakarta.

Otaya, Liang G. (2011). Pengetahuan, Sikap, dan Tindakan Masyarakat terhadap Penggunaan jamban Keluarga. Hal 1-13

Proverawati, Atikah., \& Rahmawati, Eni. (2012). PHBS Perilaku Hidup Bersih dan Sehat. Nuha medika : Yogyakarta.

Pebriani, Ayu Rahma, dkk. (2012). Faktor-faktor yang berhubungan dengan Penggunaan Jamban Keluarga dan Kejadian Diare di Desa Tualang Sembilar Kecamatan Bambel Kabupaten Aceh Tenggara. Hal : 1-5.

Stikes Panrita Husada Bulukumba. (2017). Buku Panduan Penyusunan Skripsi. 
Syamsuddin, et.al., (2015). Pedoman

Praktis Metodologi Penelitian

Internal : Pendekatan Kualitatif,

Kuantitatif, Pengembangan Dan

Mix-Method, Wade Group :

Ponorogo.

Setiadi. (2013). Konsep dan Praktik Penulisan Riset Keperawatan.ed :

2. Graha : yogyakarta.

Sugiyono. (2012). Metodologi Penelitian Kualitatif, Kualitatif dan $R \& D$. Alfabeta : Bandung.

Sumantri (2010). Kesehatan Lingkungan dan Perseptif Islam. Tramedia : Yogyakarta
Sujarweni, V.W. (2014). Metodologi Penelitian.Gava Media : Yogyakarta.

Yusuf, Meiske. (2013). Faktor-faktor Pemanfaatan Jamban Keluarga oleh Masyarakat Desa Tabumela Kecamatan Tilango Kabupaten Gorontalo. Hal 1-12.

WHO. (2010). Diakses melalui http://eprints.ums.ac.id/338544/4/B AB\%20I.pdf. Pada tanggal 28 februari 2017. 


\section{Tabel 1}

Distribusi Frekuensi Berdasarkan Karakteristik responden $(\mathbf{n}=60)$.

\begin{tabular}{ccc}
\hline Karakteristik respoden & $\mathbf{n}$ & $\mathbf{( \% )}$ \\
\hline Umur & & \\
Remaja & 11 & 18,3 \\
Dewasa & 37 & 61,7 \\
Lansia & 12 & 20,0 \\
Jenis kelamin & & \\
& & \\
Laki - laki & 56 & 93,3 \\
Perempuan & 64 & 6,7 \\
Pekerjaan & & \\
Petani & 42 & 70,0 \\
Wiraswasta & 4 & 6,7 \\
Buruh & 8 & 13,3 \\
tidak bekerja & 6 & 10,0 \\
\hline
\end{tabular}

Tabel 2

Distribusi Frekuensi jumlah responden berdasarkan tingkat pendidikan, pengetahuan, dan sikap dengan kepemilikan jamban keluarga.

\begin{tabular}{lcc}
\hline \multicolumn{1}{c}{ Varibel } & n & \% \\
\hline Tingkat pendidikan & & \\
$\quad$ Tidak sekolah & 18 & 30,0 \\
Dasar & 29 & 48,3 \\
Menengah & 13 & 21,7 \\
Tingkat pengetahuan & & \\
Baik & 15 & 25,0 \\
Cukup & 29 & 48,3 \\
Kurang & 16 & 26,7 \\
Sikap & & \\
Positif & 37 & 61,7 \\
Negatif & 23 & 38,3 \\
Kepemilikan jamban keluarga & & \\
Memiliki Jumlah & 30 & 50,0 \\
Tidak memiliki & 30 & 50,0 \\
\hline \multicolumn{2}{c}{ Ja) } \\
\hline
\end{tabular}




\section{Tabel 3}

Hubungan Tingkat Pendidikan, Pengetahuan, dan Sikap dengan Kepemilikan Jamban Keluarga

\begin{tabular}{|c|c|c|c|c|c|c|}
\hline \multirow{3}{*}{$\begin{array}{l}\text { Tingkat } \\
\text { pendidikan }\end{array}$} & \multicolumn{4}{|c|}{ Kepemilikan jamban keluarga } & \multirow{3}{*}{ Total } & \multirow{3}{*}{$\boldsymbol{P}$} \\
\hline & \multicolumn{2}{|c|}{ Memiliki } & \multicolumn{2}{|c|}{ Tidak memiliki } & & \\
\hline & $\mathbf{n}$ & $\%$ & $\mathbf{n}$ & $\%$ & & \\
\hline Tidak sekolah & 3 & 16,7 & 15 & 83,3 & 18 & \multirow{3}{*}{$0,001 *$} \\
\hline Dasar & 18 & 60,0 & 12 & 40,0 & 30 & \\
\hline Menengah & 9 & 75,0 & 3 & 25,0 & 12 & \\
\hline \multirow{3}{*}{$\begin{array}{l}\text { Tingkat } \\
\text { pengetahuan }\end{array}$} & \multicolumn{4}{|c|}{ Kepemilikan jamban keluarga } & \multirow{3}{*}{ Total } & \multirow{3}{*}{$\boldsymbol{P}$} \\
\hline & \multicolumn{2}{|c|}{ Memiliki } & \multicolumn{2}{|c|}{ Tidak memiliki } & & \\
\hline & $\mathbf{n}$ & $\%$ & $\mathbf{n}$ & $\%$ & & \\
\hline Baik & 12 & 80,0 & 3 & 20,0 & 15 & \multirow{3}{*}{$0,001^{*}$} \\
\hline Cukup & 15 & 51,7 & 14 & 48,3 & 29 & \\
\hline Kurang & 3 & 18,8 & 13 & 81,2 & 16 & \\
\hline \multicolumn{7}{|c|}{ Kepemilikan jamban keluarga } \\
\hline \multirow[t]{2}{*}{ Sikap } & \multicolumn{2}{|c|}{ Memiliki } & \multicolumn{2}{|c|}{ Tidak memiliki } & \multirow[t]{2}{*}{ Total } & \multirow[t]{2}{*}{$\boldsymbol{P}$} \\
\hline & $\mathbf{n}$ & $\%$ & $\mathbf{n}$ & $\%$ & & \\
\hline Positif & 27 & 73,0 & 10 & 27,0 & 37 & \multirow{2}{*}{$0,000 *$} \\
\hline Negatif & 3 & 13,0 & 20 & 87,0 & 23 & \\
\hline
\end{tabular}

